\title{
ANALYSIS OF MEDICINAL PROPERTIES OF VIGNA ACONITIFOLIA (MATKI)
}

\section{SUNEETA PANICKER* , ANAM HAMDULE}

Department of Microbiology, Dr. D. Y. Patil Arts, Commerce and Science College, Pune, Maharashtra, India. Email: Suneeta.panicker@dypvp.edu.in

Received: 21 February 2021, Revised and Accepted: 02 April 2021

\section{ABSTRACT}

Objective: The seeds and sprouts of matki bean (Vigna aconitifolia), a common food, contain abundant nutrients with biological activities. This work was focused to analyze and compare the medicinal properties of seeds and sprouts of matki beans, with the goal of providing scientific evidence for better application of this commonly used food as a medicine.

Methods: Using Soxhlet apparatus, ethanol extracts of matki bean sprouts and seeds were prepared. Anti-inflammatory activity (inhibition of protein denaturation, inhibition of heat induced hemolysis, and inhibition of protease activity), antioxidant activity, and antihypertensive activity were determined for both sprout and seed extracts.

Results: The anti-inflammatory activity of sprout ethanol extract was found to be highest. Sprout ethanol extract inhibited the activity angiotensin-Iconverting enzyme (ACE1) which was maximum as compared to seed extracts. Same was observed for the antioxidant activity, sprout ethanol extract showed higher activity than the seed extract.

Conclusion: The results of the present study will help us to use Vigna aconitifolia as a healthy herbal alternative for the existing chemical remedies for various disorders and rule out the issue of side effects and resistance.

Keywords: Vigna aconitifolia, Matki bean sprouts, Matki bean seeds, Angiotensin-I-converting enzyme, Anti-inflammatory activity.

(C) 2021 The Authors. Published by Innovare Academic Sciences Pvt Ltd. This is an open access article under the CC BY license (http://creativecommons.org/ licenses/by/4.0/) DOI: http://dx.doi.org/10.22159/ajpcr.2021v14i5.41186. Journal homepage: https://innovareacademics.in/journals/index.php/ajpcr

\section{INTRODUCTION}

Mung bean, lentils, moth bean, soybeans, dry beans, green beans and peas, and many such legumes make a predominant part of our diet throughout the globe and largely in the developing countries. India is one of the important legume producing nations that account $29 \%$ of world area and 19\% of world production [1]. A drought-resistant legume, Vigna aconitifolia (matki), belonging to the family Fabaceae, is regularly cultivated in the barren and semi-barren regions of India. It is also known as mat bean, moth bean, matki, Turkish gram, or dew bean. Protein rich sprouts and seeds are routinely included by the Indians in their meals. Sprouts of Vigna aconitifolia showed predominant increase in phenolic compounds such as caffeic acid, ferulic acid, cinnamic acid, and kaempferol that act as free radical scavenger [2].

The seeds of moth beans are used medicinally in diets to treat fevers. The roots are said to be narcotic [3]. It is also shown to contain trypsin inhibitor, tannins phytic acid, and antioxidant activity [4,5]. Natural antioxidants and phytochemicals are bioactive compounds present in plants that can be used to treat or prevent various diseases [6]. Thus, it is highly important in search these compounds reduce the incidence of certain cancers and potent anti-inflammatory nature. The mung (Vigna radiata) has been studied extensively and shown to have many different medicinal properties but the matki which belongs to the same family is not that widely researched. The potential of plant secondary metabolites as a source of new ACE inhibitors remains underexploited and only a limited number of plant species have been screened for this target. Thus, the present study aimed to analyze the phytochemicals present in matki and thus to investigate the different medicinal properties of it, which will help us to use it as a healthy herbal alternative for the existing chemical remedies for various disorders and rule out the issue of their side effects and resistance.

\section{MATERIALS AND METHODS}

\section{Plant materials}

Matki sprouts and dried matki seeds were procured from local market and ground to fine paste and powder, respectively, using mechanical grinder.

\section{Preparation of extracts}

The $30 \mathrm{~g}$ seed powder/30 g of sprout paste with $300 \mathrm{ml}$ of absolute ethanol were subjected to solvent extraction in Soxhlet apparatus. Each extract was divided into two proportions. One was concentrated by evaporation to $1 / 4^{\text {th }}$ the volume (diluted extracts) and the other was evaporated completely, which was then resuspended in dimethyl sulfoxide (concentrated extracts).

\section{Anti-inflammatory assay}

Inhibition of protein denaturation [7]

Five hundred microliters of $1 \%$ bovine serum albumin were added to $100 \mu \mathrm{l}$ of respective extract. This mixture was kept at room temperature for $10 \mathrm{~min}$, followed by heating at $51^{\circ} \mathrm{C}$ for $20 \mathrm{~min}$. The resulting solution was cooled down to room temperature and absorbance was recorded at $660 \mathrm{~nm}$. Acetyl salicylic acid was taken as a positive control. Percent inhibition for protein denaturation was calculated using:

$$
\text { Inhibition }[\%]=\frac{100-\left[A_{I} \times 100\right]}{A_{C}}
$$

Where, $A_{I}$ is the measured absorbance in the presence of an inhibitor and $A_{C}$ is the absorbance of the control.

\section{Heat-induced hemolysis [7]}

A volume of $100 \mu \mathrm{l}$ of $10 \%$ RBC was added to $100 \mu \mathrm{l}$ of the extract. The resulting solution was heated at $56^{\circ} \mathrm{C}$ for 30 min followed 
by centrifugation at $2500 \mathrm{rpm}$ for $10 \mathrm{~min}$ at room temperature. Supernatant was collected, and absorbance was read at $560 \mathrm{~nm}$. Acetyl salicylic acid (aspirin) was used as a positive control. Percent membrane stabilization activity was calculated using the following formula

$$
\text { Inhibition }[\%]=\frac{100-\left[A_{I} \times 100\right]}{A_{C}}
$$

Where, $A_{l}$ is the measured absorbance in the presence of an inhibitor and $A_{C}$ is the absorbance of the control.

\section{Protease inhibition assay [7]}

One hundred microliters of $1 \%$ bovine serum albumin were added to $100 \mu \mathrm{l}$ of extract. This was incubated at room temperature for $5 \mathrm{~min}$. Reaction was inhibited by the addition of $250 \mu$ of trypsin followed by centrifugation. The supernatant was collected, and absorbance was observed at $210 \mathrm{~nm}$. Acetyl salicylic acid (aspirin) was used as a positive control. Percent inhibition of protease inhibition was calculated.

$$
\text { Inhibition }[\%]=\frac{100-\left[A_{I} \times 100\right]}{A_{C}}
$$

Where, $A_{I}$ is the measured absorbance in the presence of an inhibitor and $A_{C}$ is the absorbance of the control.

\section{Antioxidant assay [8]}

The free radical scavenging activity of the extracts was determined using in vitro assay as described by Jamuna et al., with slight modifications. This method is based on the reduction of $\left(\mathrm{Fe}^{3+}\right)$ ferricyanide and the reduction of $\mathrm{Fe}^{3+}$ to $\mathrm{Fe}^{2+}$ was determined by measuring the absorbance. Five hundred microliters of extract were mixed with $2.5 \mathrm{ml}$ of $0.2 \mathrm{M}$ sodium phosphate buffer ( $\mathrm{pH} 6.6$ ) and $2.5 \mathrm{ml}$ of $1 \%$ potassium ferricyanide followed by incubation at $50^{\circ} \mathrm{C}$ for $20 \mathrm{~min}$. After adding $2.5 \mathrm{ml}$ of $10 \%$ trichloroacetic acid, the mixture was centrifuged at $3000 \mathrm{rpm}$ for $10 \mathrm{~min}$. The supernatant was collected in a fresh tube and mixed with $2.5 \mathrm{ml}$ of distilled water and $0.5 \mathrm{ml}$ of $1 \%$ ferric chloride. This mixture was incubated for $10 \mathrm{~min}$ and then absorbance was measured at $700 \mathrm{~nm}$. Higher absorbance of the reaction mixture indicates reductive potential of the extracts. Ascorbic acid was used as positive control.

\section{Antihypertensive assay [9]}

The antihypertensive assay was performed as described by Serra et al., using rabbit lung solution as the source of ACE with slight modification. Five hundred microliters of the rabbit lung solution $(1 \mathrm{~g} / 10 \mathrm{ml})$ were added to $500 \mu \mathrm{l}$ of the extract solution to be tested, or $500 \mu \mathrm{l}$ of 50 $\mathrm{mmol} / \mathrm{l}$ phosphate buffer, $\mathrm{pH} 8.3$ (negative control) or $500 \mu \mathrm{l}$ of captopril solution (64 nmol/l) (positive control). The mixture was homogenized and pre-incubated for $5 \mathrm{~min}$ at $37^{\circ} \mathrm{C}$. The enzymatic reaction was started by adding $600 \mu \mathrm{l}$ of the assay buffer and $300 \mu \mathrm{l}$ of the substrate solution (hippuryl-glycyl-glycine, Hip-Gly-Gly $100 \mathrm{mmol} / \mathrm{l}$ ). After homogenization, the mixture was incubated for $35 \mathrm{~min}$, at $37^{\circ} \mathrm{C}$. The reaction was stopped by the addition of $500 \mu$ l of sodium tungstate solution (100 g/l) and $500 \mu \mathrm{l}$ of sulfuric acid ( $0.33 \mathrm{mmol} / \mathrm{l})$; the flask was mixed for $10 \mathrm{~s}$, following addition of $1000 \mathrm{ml}$ of distilled water.
After that, the mixture was centrifuged at $2000 \mathrm{rpm}$, for $10 \mathrm{~min}$. An aliquot of the supernatant $(75 \mu \mathrm{l})$ was placed on a microtiter plate and mixed with $100 \mu \mathrm{l}$ of phosphate buffer (100 mmol/l, pH 8.5) and $5 \mu \mathrm{l}$ of TNBS solution. The plate was kept in the dark, at room temperature, for $20 \mathrm{~min}$. Later, its absorbance was read in a microtiter plate reader at $415 \mathrm{~nm}$ against a blank solution prepared in a similar way, except for adding the sodium tungstate and the sulfuric acid solutions before the rabbit lung solution. Calculation of ACE inhibition, on percentile basis, was accomplished by the following equation:

$$
\text { Inhibition }[\%]=\frac{100-\left[A_{I} \times 100\right]}{A_{C}}
$$

Where, $A_{I}$ is the measured absorbance at $415 \mathrm{~nm}$ in the presence of an inhibitor and $A_{C}$ is the absorbance of the blank solution.

\section{RESULTS}

\section{Anti-inflammatory assay}

Inhibition of protein denaturation

The sprout diluted extract showed 56\% of maximum inhibition of protein denaturation whereas powdered concentrated extract showed only $10 \%$ inhibition. Sprout extract was effective in inhibiting heat-induced albumin denaturation. The $\%$ inhibitions of protein denaturation are mentioned in Table 1 . Aspirin, which was used as a known positive control, showed the maximum inhibition $64.89 \%$ at the concentration of $100 \mu \mathrm{g} / \mathrm{ml}$. Capacity of Vigna aconitifolia extract to reduce the heat-induced denaturation of protein is possibly a contributing factor for its anti-inflammatory activity.

\section{Heat-induced hemolysis}

The sprout diluted extract showed a maximum of $66 \%$ of inhibition by heat-induced hemolysis whereas powdered concentrated extract showed only $26 \%$. The $\%$ inhibitions of heat-induced hemolysis are mentioned in Table 1. Aspirin showed the maximum inhibition 76.57\% at $100 \mu \mathrm{g} / \mathrm{ml}$. Protein denaturation is a well-documented cause of inflammation. Thus, sprout diluted extract was effective in inhibiting the heat-induced hemolysis and present capability of membrane stabilization which is one of the anti-inflammatory mechanisms.

\section{Protease inhibition assay}

The sprout diluted extract showed a maximum of $93 \%$ of protease inhibition as compared to powdered diluted, sprout ethanol concentrated, and powdered concentrated. The \% inhibitions of protease inhibition assay are mentioned in Table 1 . Aspirin showed the maximum inhibition $62.43 \%$ at $100 \mu \mathrm{g} / \mathrm{ml}$. These extracts showed significant antiproteinase activity. This effect may be due to the inhibition of release of lysosomal content of neutrophils at the inflammation site. It is a well-known fact that the proteinases from the leukocytes are responsible for the tissue damage in the inflammatory sites. Thus, proteinase inhibition provides a significant protection in such conditions.

\section{Antihypertensive assay}

The pathogenesis of hypertension is related to angiotensin, a

\begin{tabular}{|c|c|c|c|c|}
\hline Extract & $\begin{array}{c}\text { \% inhibition of protein } \\
\text { denaturation (albumin } \\
\text { denaturation) }\end{array}$ & $\begin{array}{c}\text { \% inhibition of heat-induced } \\
\text { hemolysis (membrane } \\
\text { stabilization) }\end{array}$ & $\begin{array}{c}\% \text { inhibition of } \\
\text { protease inhibition } \\
\text { (proteinase inhibition) }\end{array}$ & $\begin{array}{c}\text { \% ACE inhibition } \\
\text { (antihypersensitivity } \\
\text { activity) }\end{array}$ \\
\hline Sprout diluted & 56 & 66 & 93 & 67.5 \\
\hline Powder diluted & 40 & 33 & 82 & 26.85 \\
\hline Sprout concentrated & 40 & 39 & 82 & 51.15 \\
\hline Powder concentrated & 36 & 26 & 82 & 17.9 \\
\hline Positive control & (aspirin) 67.8 & (aspirin) 76.57 & (aspirin) 62.43 & (captopril) 69.5 \\
\hline
\end{tabular}
decapeptide. It is produced after the action of ACE, so inhibitors to

Table 1: Results of protein denaturation, heat-induced hemolysis, protease inhibition assay, and antihypertensive assay 
ACE can be used to normalize the blood pressure in hypertensive patients. ACE inhibition was observed maximum in sprout diluted extract and minimum in powdered concentrated extract. These results demonstrate the presence of ACE inhibitory compounds in the extracts. The \% inhibition of ACE for all extracts is mentioned in Table 1. Sprout diluted extract exerts significant inhibition on ACE activity. A known ACE inhibitor, captopril, was used as a positive control.

\section{Antioxidant assay}

There is a very well-established direct correlation between the reducing power of certain plant extracts and antioxidant activities. The sprout diluted extract showed higher reducing power than the powdered diluted, sprout concentrated, and powdered concentrated extract. The reducing capability of various extracts is mentioned in Table 2 . The phenolic antioxidant mechanism depends on Fe (III) reduction by the electron-donating activity of the extract.

\section{DISCUSSION}

The medicinal importance of legumes is due to the presence of pharmaceutical compounds for curing or improving human health. The various types of phytochemicals are studied from legumes by many researchers. The phytochemicals act as antioxidant, anti-inflammatory, and prevention of many diseases such as obesity, aging, diabetes, heart-related diseases, and many health-related problems to cure and prevention of many physiological disorders as therapeutics [1].

Trypsin inhibitors were appreciated for reducing the incidence of certain cancers and potent anti-inflammatory properties. Protease inhibitors are suggested as potential drugs for treating various diseases such as human immunodeficiency virus (HIV), hypertension, and neurodegenerative disease, along with various infectious diseases [10]. In our study, the sprout diluted extract exhibited significant antiproteinase activity and showed maximum inhibition of $93 \%$.

Denaturation of proteins is also a well-documented cause of inflammation. Protein denaturation was studied by bovine serum albumin denaturation method. The test extracts were effective in inhibiting heat-induced albumin denaturation. Inhibition of $56 \%$ was observed from diluted extract of sprout. All the extracts inhibited the albumin denaturation. In a parallel study, the antiinflammatory activity of the whole plant methanolic extract of Smithia sensitiva, which belongs to the family of matki, was shown to be $68.30 \%$ inhibition that was determined by using similar method used in this study [11]. The higher $\%$ inhibition in their study may be due to the usage of whole plant.

In the present study, the inhibition of heat-induced RBC membrane lysis, that is, stabilization of RBC membrane was taken as a measure of the antiinflammatory activity. All the extracts were effective in inhibiting the heatinduced hemolysis. These provide evidence for membrane stabilization as an additional mechanism of their anti-inflammatory effect. These extracts may possibly inhibit the release of lysosomal content of neutrophils at the site of inflammation. The sprout extract of Vigna aconitifolia for in vitro anti-inflammatory activity by heat-induced hemolysis method showed inhibition of $66 \%$. Comparably, in another study, the aqueous extract of the flower part of Gliricidia sepium which also belongs to the same family of matki was studied for in vitro anti-inflammatory activity by RBC membrane stabilization method. The plant extract showed dose-dependent anti-inflammatory activity and \% hemolysis of RBC in hypotonic solution which was observed to be $92.8 \%$ [12].

Table 2: Reducing power activity of all extracts

\begin{tabular}{lc}
\hline Extract & Absorbance at $\mathbf{7 0 0} \mathbf{~ n m}$ \\
\hline Sprout diluted & 0.73 \\
Powder diluted & 0.56 \\
Sprout concentrated & 0.67 \\
Powder concentrated & 0.48 \\
Positive control & [ascorbic acid] 0.84 \\
\hline
\end{tabular}

Reducing activity is often used to evaluate the ability of natural antioxidant to donate electron. Sprout diluted extract showed antioxidant activity of $62 \%$. Another study [8] showed consistent increase in the reducing power of methanolic leaf and root extracts of $H$. radicata with the increase in the volume of extract. When compared with the root extract $(0.433$ at $700 \mu \mathrm{g} / \mathrm{ml})$, leaf extract showed higher absorbance $(1.092$ at $600 \mu \mathrm{g} / \mathrm{ml})$.

The use of angiotensin I-converting enzyme inhibitor (ACE-I) is well established as one of the primary therapeutic agents for the treatment of hypertension. However, all synthetic ACE-I drugs can cause some side effects such as dizziness, cough, and edema angioneurotic. Phenolic compounds in some plants were reported to lower blood pressure through inhibition and decrease the expression of ACE. Phenolic compounds, such as flavonoids interact with ACE, thus can inhibit ACE action [13]. Peptic hydrolysate of partially purified protein of Vigna unguiculata (Cow pea) inhibited the activity angiotensin-I-converting enzyme by $85.5 \%$ [14]. In our study, the sprout ethanol diluted extract inhibited the activity angiotensin-I-converting enzyme by 67.50 , which was observed to be maximum when compared to other extracts. Percent ACE inhibition value at concentration $100 \mu \mathrm{g} / \mathrm{ml}$ of Vigna unguiculata leaves was $23.77 \%$ [13]. The difference in the inhibition percent may be due to the difference in the species of the extracts used. Along with the mung beans, many different plant-derived extracts (rice, wheat, soybean, and corn) have shown to contain peptide/proteins possessing antihypersensitivity $[15,16]$. The natural phytochemicals that are responsible for the ACE inhibitory are procyanidins and flavonoids [17-19].

\section{CONCLUSION}

In the present study, the moth bean sprout diluted extract was found to be most effective for all the tests performed. Further studies involving the isolation and purification of the chemical constituents of the plant and the investigations in the biochemical pathways may result in the development of a potent therapeutic agent with a low toxicity and better index. These encouraging results further reflect a hope for the development of a more novel.

\section{AUTHORS' CONTRIBUTIONS}

All the authors have prepared the conception, data collection, data analysis, interpretation and drafting of the article, and also discussed the methods, results, and contributed to the final manuscript. Dr. Suneeta Panicker supervised the whole work until the completion of manuscript.

\section{CONFLICTS OF INTEREST}

No conflicts of interest, financial, or otherwise.

\section{AUTHORS' FUNDING}

This research received no external funding.

\section{REFERENCES}

1. Verma N, Sehrawat K, Ahlawat A, Sehrawat A. Legumes: The natural products for industrial and medicinal importance-A review. Int J Cell Sci Biotechnol 2017;6:6-13.

2. Kestwal M, Bagal-Kestwal D, Chiang BH. Analysis and enhancement of nutritional and antioxidant properties of Vigna aconitifolia sprouts. Plant Foods Hum Nutr 2012;67:136-41.

3. Brink M, Jansen PC. Vigna aconitifolia (Jacq.) Maréchal. In: Brink M, Belay G, editors. Plant Resources of Tropical Africa. Wageningen: PROTA Foundation; 2006.

4. Mandal S, Mandal RK. Seed storage proteins and approaches for improvement of their nutritional quality by genetic engineering. Curr Sci 2000;79:576-89.

5. Millerd A. Biochemistry of legume seed proteins. Annu Rev Plant Physiol 1975;26:53-72.

6. Roy F, Boye J, Simpson B. Bioactive proteins and peptides in pulse crops: Pea, chickpea and lentil. Food Res Int 2010;43:432-42.

7. Reshma, Arun KP, Brindha P. In vitro anti-inflammatory, antioxidant and nephroprotective studies on leaves of Aegle marmelos and Ocimum 
sanctum. Asian J Pharm Clin Res 2014;7:121-9.

8. Jamuna S, Paulsamy S, Karthika K. Screening of in vitro antioxidant activity of methanolic leaf and root extracts of Hypochaeris radicata $\mathrm{L}$. (Asteraceae). J Appl Pharm Sci 2012;2:149-54.

9. Serra CP, Cortes SF, Lombard JA, Braga de Oliveira A, Braga FC. Validation of a colorimetric assay for the in vitro screening of inhibitors of angiotensin-converting enzyme (ACE) from plant extracts. Phytomedicine 2005;12:424-32.

10. Gupta N, Shrivastava N, Singh P, Bhagyawant S. Phytochemical evaluation of moth bean (Vigna aconitifolia L.) seeds and their divergence. Biochem Res Int 2016;2016:3136043.

11. Sreena K, Nair S. Evaluation of anti-inflammatory activity of the plant extract Smithia Sensitiva. Sch Res Libr 2016;8:310-6.

12. Kumar KP, Naik VS, Chandra BV, Lavanya R, Kumar KN, Bhagyasree $\mathrm{V}$, et al. Evaluation of in vitro and in vivo anti-inflammatory activity of aqueous extract of Gliricidia sepium flowers in rats. Int J Pharmacogn Phytochem Res 2014;6:477-81.

13. Rumiyati R, Sudarsono, Susanto BO, Mayasari SK, Wijaya RN. In vitro ACE inhibitory assay of extracts containing flavonoid-phenolic compounds of edible plants. Int J Pharm Clin Res 2016;8:414-8.

14. De Leon R, Torio MA, Manalo M, Aguda R. A Dipeptide with Antihypertensive Activity from Cowpea (Vigna unguiculata) Seed 7S Globulin. Phillipines: National Academy of Science and Technology; 2014. p. 171

15. Hong F, Ming L, Yi S, Zhanxia L, Yongquan W, Chi L. The antihypertensive effect of peptides: A novel alternative to drugs? Peptides 2008;29:1062-71.

16. Guang C, Phillips R. Plant food-derived angiotensin I converting enzyme inhibitory peptides. J Agric Food Chem 2009;57:5113-20.

17. Wagner H, Elbl G, Lotter H, Guinea M. Evaluation of natural products as inhibitors of angiotensin I-converting enzyme (ACE). Pharm Phamacol Lett 1991;1:15-8.

18. Lacaille-Dubois MA, Franck U, Wagner H. Search for potential angiotensin converting enzyme (ACE)-inhibitors from plants. Phytomedicine 2001;8:47-52.

19. Actis-Goretta L, Ottaviani JI, Keen CL, Fraga CG. Inhibition of angiotensin converting enzyme (ACE) activity by flavan-3-ols and procyanidins. FEBS Lett 2003;555:597-60. 